\title{
Post-Secular Identity? Developing a New Approach to Religion in International Relations and IR Studies
}

\author{
Joanna Kulska 1,*(D) and Anna M. Solarz ${ }^{2, *(D)}$ \\ 1 Institute of Political Science and Administration, Faculty of Political Science and Social Communication, \\ University of Opole, 45-061 Opole, Poland \\ 2 Department of Regional and Global Studies, Faculty of Political Science and International Studies, \\ University of Warsaw, 00-927 Warsaw, Poland \\ * Correspondence: jkulska@uni.opole.pl (J.K.); asolarz@uw.edu.pl (A.M.S.)
}

Citation: Kulska, Joanna, and Anna M. Solarz. 2021. Post-Secular Identity? Developing a New Approach to Religion in International Relations and IR Studies. Religions 12 982. https://doi.org/10.3390/ rel12110982

Academic Editor: Jeffrey Haynes

Received: 30 September 2021

Accepted: 3 November 2021

Published: 10 November 2021

Publisher's Note: MDPI stays neutral with regard to jurisdictional claims in published maps and institutional affiliations.

Copyright: (c) 2021 by the authors. Licensee MDPI, Basel, Switzerland. This article is an open access article distributed under the terms and conditions of the Creative Commons Attribution (CC BY) license (https:/ / creativecommons.org/licenses/by/ $4.0 /)$.
Abstract: In spite of the increasing presence of religion in international relations with various publications observing this presence and numerous authorities calling for the inclusion of religion into mainstream research, there is no universal consent to recognize religion's role in IR. In our opinion, the only way to reconcile IR with the international reality in which religion has been and will remain present in the foreseeable future is for the researchers themselves to construct-especially those oriented towards broad, non-Western perspective-a new face of the discipline, the face which in this article we call the post-secular identity of IR study. Assuming that identity is first and foremost a form of knowledge that tells us how we can define ourselves against the background of the surrounding world, our purpose is to look at the post-secular identity from two different perspectives which are analyzed in the two distinctive parts of the paper. On one hand, post-secular identity would mean the socio-political but also cultural phenomenon of the "knowledge of the self" expressed in the form of ideas, interests and goals of various state and nonstate actors, both religious and secular ones, that are more or less conditioned by religious determinants. We propose looking at them through the prism of a new kind of "partnership" emerging as a result of post-secular thinking in the area of IR. On the other hand, we want to look at post-secular identity as the badly required transformation within the area of IR study that, as we claim, needs to construct more inclusive views of IR scholars adopting a deliberative and pluralistic approach to the reality they examine based on widening their epistemological and hermeneutical horizons. This redefinition would be framed by recognizing religion as rational and adopting the view that the limits of the scientific methods do not coincide with the boundaries of rationality. We also adopt the view that along with the cognitive expansion of the universe, the concept of transcendence has been broadened.

Keywords: religion; IR/ir; post-secularism; post-secular identity of IR studies; secular-religious partnership; mediated hermeneutic matrices of religion and secularism; philosophy of science and IR

\section{Introduction}

In spite of the increasing presence of religion in international relations with various publications observing this presence and numerous authorities calling for the inclusion of religion into mainstream research, there is no universal consent to recognize religion's role in IR. In our opinion, the only way to reconcile IR with the international reality in which religion has been and will remain present in the foreseeable future, is for the researchers themselves to construct, especially those oriented towards broad, non-Western perspectives, a new face of the discipline, the face which in this article we call the post-secular identity of IR study.

This identity which is already formed at the level of the philosophy of social sciences, i.e., metatheory, does not destroy hitherto achievements of the discipline, nor does it require resignation from established methodologies. On the other hand, it opens IR to still neglected, often non-Western theories and research approaches, especially those in which 
religion demands its rightful place, but at the same time does not allow it to dominate the scientific discourse. It is an approach that does not exclude but affirms different points of view and worldviews, allowing the IR to actually become the broadest discipline of the humanities. An advantage of the post-secular identity of the IR could be the influence of this discipline on the rationalization of religious discourse, especially the fundamentalist one that destabilizes international relations. Finally, such reconceptualization could contribute to the development of a more effective secular-religious relation enhancing not only theoretical but also the practical dimension of what has been the key of post-secular perspective namely "mutual process of learning" between the religious and the secular (Ratzinger and Habermas 2006; Mavelli and Petito 2012).

Assuming that identity is first and foremost a form of knowledge that tells us how we can define ourselves against the background of the surrounding world (Misztal 2000, p. 75), our purpose is to look at the post-secular identity from two different perspectives which are analyzed in the two distinctive parts of the paper.

On the one hand, post-secular identity would mean the socio-political but also cultural phenomenon of the "knowledge of the self" expressed in the form of ideas, interests and goals of various state and nonstate actors, both religious and secular ones, that are more or less conditioned by religious determinants. We propose looking at them through the prism of new kind of "partnership" emerging as a result of post-secular thinking in the area of ir and IR (Petito et al. 2021).

On the other hand, we want to look at post-secular identity as the badly required transformation within the area of IR study that, as we claim, needs to construct more inclusive views of IR scholars adopting a deliberative and pluralistic approach to the reality they examine based on widening their epistemological and hermeneutical horizons. This redefinition would be framed by recognizing religion as rational and adopting the view that the limits of the scientific methods do not coincide with the boundaries of rationality. We also adopt the view that along with the cognitive expansion of the universe, the concept of transcendence has been broadened (Heller 2021).

We situate our arguments within the ongoing debate on the epistemology of IR which we perceive as the "struggle over narration". In this context, we propose looking at the discourse on religious-secular dichotomy as one of the examples, perhaps the crucial ones, of the monologic, exclusionary and hegemonic discourse in IR as such. In this regard, we join the epistemic community of those calling for the transformation of IR towards a more pluralistic, inclusive, and culture-sensitive approach recognizing religion as an asset, not just as an obstacle, in ir and IR. We claim that the call for rethinking the role of religion in ir and IR needs to be perceived as the element of reconceptualizing IR as such aimed at the pluralization and democratization of the discipline (Buzan and Acharya 2019). In this process, the postulated transformation of the discourse would be both the instrument and the purpose.

In the article, we adopt a constructivist approach following the assumption that while theories influence the perception of reality, they also create it.

\section{Religion in ir and IR: Where Are We?}

In 2021, results of the new World Value Survey (WVS) have been published pointing to "people beliefs" as one of the most significant factors determining contemporary socialpolitical reality. As the authors summarize, "The WVS has over the years demonstrated that people's beliefs play a key role in economic development, the emergence and flourishing of democratic institutions, the rise of gender equality, and the extent to which societies have effective government" (World Values Survey 2021). The data collected by Ronald Inglehart with different collaborators over the course of the last forty years has been a strong voice on the side of those supporting the theory of secularization. As Ronald Inglehart indicated, there is a direct correlation between modernization processes and the change in values from traditional values towards secular-rational values and survival values towards self-expression values (Norris and Inglehart 2004; Inglehart 2021). 
However, numerous authors have argued that at the same time, namely from the 1970s, religion has increasingly entered, or re-entered, politics and more generally the public sphere, both at the domestic and international level (Kepel 2010; Casanova 1994; Berger 1999; Toft et al. 2011; Huntington 2005; Philpott 2002, 2009). From the regional approaches and country case studies evidencing examples of growing religious influence in the socio-political area through the social strata analysis emphasizing vitality of religious values, religion turned out to be crucial normative and legitimizing determinant (Singleton 2014; Berger 1999). At the same time though, it re-affirmed its role as the key self-identification and mobilization determinant (Eisenstadt 2005; Kratochwil 2005; Shani 2014). Contrary to the secularization theory, those developments appeared to be not only the reality of "backward" theocracies and countries with a low level of independence between religion and politics (Toft et al. 2011) but also those representing the model of strict separation. In the USA, the growing political role of religious groups, especially those of an evangelical nature, led to significant reconfiguration of domestic and foreign policy (Marsden 2012). Similarly, in virtually none of the European countries are significant issues of the relationship between religious organizations, society and the state completely absent from the political agenda. The "chimera of neutrality", as John Madeley and Zsolt Eneydi called the model of separation between state and religion, did not prevent religion to be increasingly present in the public debate (Madeley and Eneydi 2003). Moreover, this presence has also been growing at the EU level, eventually resulting in the concept of "regular, open and transparent dialogue" between EU institutions introduced in the article 17 Lisbon Treaty and the concept of the post-secular Europe emerging in the academic debate (Fokas 2009). In Central-Eastern Europe, religion turned out to be the crucial self-identification element (Pew Research Center 2017).

Since the 1990s, many concepts questioning the secularization theory have emerged introducing the idea that while secularization is the process in progress, religion has found some new ways of influencing social-political reality. The observation on secularizing effects provoking counter-secularization has not only been valid but also increasingly determining of political developments (Berger 1999). The obviousness and indisputability of the secularization theory has ceased to be "universal truth" (Casanova 1994; Wilson 2012).

In the area of IR, one can speak of emerging extended and shared global space populated by religious actors and their visions of the post-secular world (Troy 2021). The increased role of religious values, ideas and actors in global politics inevitably leads to the fundamental question of how all these phenomena affect our knowledge and understanding of the world. This growing awareness on religion "meaning more" should push both common wisdom and scientific analysis into the new arenas. However, there have been some obstacles present which have created this assumably obvious process.

As Peter Berger famously stated over two decades ago, and which still represents the contemporary stage of things, the problem that we are facing is the upside-down perception of the world according to which fundamentalism is a rare, hard-to-explain thing. "But a look either at history or at the contemporary world reveals that what is rare is not the phenomenon itself but knowledge of it. The difficult-to-understand phenomenon is not Iranian mullahs but American university professors" (Berger 1999, p. 2). The simple statement that religion, though different than it was a few decades ago, "is and will be there", constantly constitutes the challenge to those whose only intellectual orientation has been the one of Westphalian myth and enlightened secularism, especially in the French "exclusive" or even "totalist" version, which is different to the "inclusive', "open" American one (Gierycz 2021).

At the same time, the negative perception of religious contributions to world affairs is difficult to be overcome in spite of the two decades of discussion on the concept ambivalence of the sacred and (Gopin 2000) thousands of peace-oriented and developmentoriented projects run by religious and faith-based actors.

Finally, in spite of an increasingly present awareness of numerous non-Western approaches which read the reality based on alternative understandings of world politics and 
world order (Tickner and Blaney 2012, pp. 2-3), superiority of the West over the "Rest" is hard to resist and the humble self-critics is hard to achieve.

The secularist inclination to substitute "Credo ergo sum" with "Cogito ergo sum" has been very successful in Western science as such, but it had an especially deep effect on the area of IR. When compared with other social sciences the "delay" or at least some kind of "discomfort" in bringing religion back has been visible. And while the "religion friendly" views are spreading, it would be hard to state that the religious perspective of "reading" the global socio-political reality has moved closer to being one of the equally valid perspectives in IR.

However, the debate is ongoing and promising because the transformation of both the theory and the practice towards "fair" inclusion of religion in the public space is slowly but consequently progressing. In the practical dimension, a new paradigm for religious-secular dialogue and partnership has been emerging in the period of the last years in such areas as foreign policy, diplomacy, security and statecraft (Appleby et al. 2010; Appleby 2021, pp. 84-85). As Mariano Barbato remarks, perhaps the return of religion in international relations does not need to be a revenge of God, as Gilles Kepel pointed out it in his path breaking book on the return of religion, but rather a source of public reasoning to cure pathologies of modernization (Barbato 2012, pp. 80-81).

\section{Post-Secularism: Towards Changing Secularist Paradigm?}

The turning points that changed the place of religion in political discourse and scientific analysis, both at the domestic and international level, have been well known and hotly debated. From Samuel Huntington's clash of civilizations, to Peter Berger's desecularization of the world, to Jose Casanova's "republicization" of religion as well as many other concepts explaining its complex essence and dynamics, religion has been "brought back" or again "noticed" in the area of IR. Framed conceptually within post-secular perspective/approach proposed by Jurgen Habermas and developed by numerous other authors over the last two decades, religion "forced" its way into the area of ir and IR. The essence of this approach has been introducing the idea that religion and the secular should meet in the public sphere and develop their relations in the mode of a "mutual learning process" beneficial for all segments of society, including both religious and nonreligious ones.

The concept given by Habermas emerged as the reaction to dynamic changes within the public sphere in the European context (Habermas 2008), but soon it was broadened. Among the numerous scholars who responded to Habermas' proposal and engaged in the development of the redefined interactions between the religious and the secular, it is worth pointing to Joseph Ratzinger who significantly contributed to the debate. In his reflection on mutual relations between religion and politics, he did not only refer to the development of relations between religion and reason that mutually "purify" each other. One of the dimensions exposed by Ratzinger was the one of looking to the "outside" non-Western world as the source of conceptual innovations to overcome a crisis increasingly experienced by Western civilization (Ratzinger and Habermas 2006).

The term post-secularism has been used in social sciences in two interconnected ways. According to the first, more descriptive fashion, it refers to the return of religious traditions in modern life. According to the second one, post-secularism is a form of theorizing and critique " (... ) prompted by the idea that the values such as democracy, freedom, equality, inclusion and justice may not necessarily be best pursued within an exclusively immanent secular framework. On the contrary, the secular may well be a potential site of isolation, domination, violence and exclusion" (Mavelli and Petito 2012).

The new post-secular perspective meant the call for the reorientation of global politics reaching beyond its Western-centric ground and emergence of the new forms of community, identity and power (Mavelli and Petito 2014). This would also imply the wide reconceptualization of the borders between the religious and the secular which were crucial for the emergence of Western modernity (Mavelli and Petito 2014, pp. 7-9). In general, this transformation would bring the partial rejection of the Western idea of universalizing 
modernity which is always linked to science, instrumental rationality and the tradition of enlightenment (Falk 2014, pp. 29-30). The essential reconceptualization also refers here to the concept of rationality as such. As Michal Heller states, the essence of religion is rationality which is aware of its limits. The question of meaning is a rational question, although it goes beyond the boundaries of the scientific method which does not coincide with the boundaries of rationality. As the cognitive universe expands, the concept of God also expands (Heller 2021). In accordance with this view, the post-secular approach brings profound change in both consciousness and sensibility regarding the relationship to the other (Ratzinger and Habermas 2006; Wilson 2012). As God is "the other", the transformed, dialogical relations to ordinary "the other" follows (Barbato and Kratochwil 2008). As a result, the complex debate on the relationship between secularization and modernity, religion and conflict, and democracy and inclusion has been reopened and reconsidered in the light of the new post-secular awareness. It is based on the necessity of 'post-secular encounters' between religious and secular understandings of being-in-the-world, of "a change of attitude in favor of a dialogical relationship, open to learning, with all religious traditions" (Cerella 2014, pp. 957-58).

The post-secular approach can be analyzed from many different perspectives: sociological, philosophical, cultural, or the semantic perspective. All of them overlap in the area of IR being one of the most complex and comprehensive disciplines of social science (Ratzinger and Habermas 2006; Barbato and Kratochwil 2008). What brings them all together as a common denominator is the one of inclusiveness of religious arguments in the public domain, and one that Mariano Barbato describes as a problem of "political theory". As he points out, stable existence at least for the present moment, of religious strata and their moral convictions, makes it impossible to ban religious arguments from the public sphere. This is not possible " (.. ) within an inclusivist liberal concept of the public, which is in dire need of support against social pathologies. Rigid secularism as a political project is therefore morally and politically wrong" (Barbato 2020, p. 2).

It is not, or rather not only, the content of the secularization theory that has been most criticized by the proponents of including religion into the IR scholarship. It is actually more about the characteristics of the discourse itself: excluding, authoritative and homogenizing. This type of discourse that is based on the zero-sum logic assumes an "either or" instead of a "both and" approach. As Erin Wilson interestingly develops this problem, she points to the fact that dualism, or dichotomous thinking, has been " (... ) a dominant tendency in Western thought, language and academic traditions. Dichotomous thinking works to separate concepts that often exist in a symbiotic relationship". As she remarks, some IR scholars have noted how these dualistic oppositions, embedded in the liberalism, have affected the understanding of world politics through " (. . ) subordination of certain contrasting elements. ( . . ) These relationships of privilege and subordination are managed in Western society by the public/private divide. Privileged concepts are situated in the public realm, while subordinate terms are privatized" (Wilson 2010, p. 739).

In IR, more than anywhere else, one can speak of the discourse that rejects any other options and leads to the dichotomic divisions inherently characterizing the approach towards religion in the Western scholarship (Wilson 2010). As a result, monologic discourse emerges that results in the narrowing of the perceived reality and its analysis. Post-secularism challenges this problem proposing a more holistic and more inclusive perspective based on a bottom-up rather than a top-down approach (Troy 2021). Therefore, the bottom layers of the society and not the top ones "can also be the preferential place for epistemology, for discovering what knowledge is, how it is constructed and in whose interests it is constructed" in the area of global politics. As such, religion also needs to be understood as part of historical progress. Simultaneously, the emergence of a new secularreligious partnership contributes to the stretching of political imagination and creating new practical innovations to respond to numerous global challenges (Petito and Thomas 2015; Petito et al. 2018; Kulska 2020). With the "post-secular", the idea emerges that a zero-sum game could be well substituted with the win-win framework of mutual relations between 
both the sacrum and the profanum emerging from the "mutual learning process" and resulting in the pluralistic, inclusive "religious-secular partnership" (Petito et al. 2021).

\section{Post-Secularism in IR: Against Homogenization of the Discourse}

Post-secularism is neither a dominating perspective in the area of political science nor in IR (Haynes 2014), yet it opens radically new possibilities of redefining the place of religion in the practical sphere of ir and well as IR. One should agree with Alexander Stumvoll (Stumvoll 2013), who points out that religion and IR literature has already moved from its first debate of "how, if at all, does religion matter?" to the current debate of "how should we study and approach religion". There is hope that the question "how can the acknowledgement and study of specific religions traditions and communities help solve or mitigate concrete cases of injustice and violence?" will be soon given closer consideration.

The answers to the second and the third questions can be effectively searched based on the perspective of the post-secular approach. This perspective needs to be viewed as an attempt to create the perspective on the role of religion that opposes the homogenized discourse in IR based on the narrowed, reductionist perception of religion. Moreover, it looks for some new instruments to advance practical developments regarding the process of mutual learning between the secular and the religious. According to Mariano Barbato's definition, "The post-secular approach is understood as an analytical tool for observation but is also regarded as a normative framework to evaluate an expanding integration of diverse social and religious strata into the public discourse without providing a comprehensive, homogenizing doctrine" (Barbato 2020). Post-secularism brings the call for recognizing conceptions of global politics proposed by religious actors as equally valid in the discourse under the condition they lead to enrichment and not the homogenization of this discourse.

Serious thinking about inequality (Troy 2021) seems to have both a theoretical and practical dimension. On the one hand, inequality refers to the hierarchy of politicalreligious discourse. One the other hand, opposing inequality refers to recognition of the post-secular approach as "equally legitimate" in the area of IR. Ideas and practices of religious actors are thus treated "at the same level" as the political concepts entering pluralistic public discourse with nonreligious actors that seek epistemological transformation. The deep pluralism of a post-secular society takes differences seriously without fearing them (Barbato 2020).

Dialogue, bridging, and partnership are the terms often present in the discourse when the post-secular approach is applied. However, those terms need to be looked at with reference to the specific, local conditions in which religious ideas and religious actors become part of the public discourse. Although religious renaissance is a complex, diversified phenomenon, it brings locally-conditioned implications in different culturalreligious contexts. Post-secularism means in fact something different in the Western and non-Western world. Calling for redefinition of the old schemes of thinking, post-secularism offers some elements of decentralization and a periphery-oriented approach. This line of thought follows the more general debate in IR on rethinking IR. The fundamental call for pluralization of the discourse arises here being in fact the element of introducing "deep pluralism" in the study of IR (Buzan and Acharya 2019). In this process aimed at pluralization and democratization of the discipline, transformation of the discourse towards a more inclusive and more culture-oriented one is to be achieved. Only this way may the call for "taking inequality seriously" be fully realized. Geocultural approaches substituting geopolitical ones may be applied provided the religious determinant is taken into consideration with its full complexity and epistemological consequences.

\section{A Post-Secular Identity of IR Studies? Interdisciplinarity and Post-Secular Philosophy as a Hope for Research on Religion in International Relations}

The interdisciplinary nature of international relations (IR), which did not come into existence by subdividing a broad discipline, but through a synthesis, ${ }^{1}$ has resulted in a 
whole range of methodological, epistemological, and even ontological issues over the course of a century (1919-2019) of academic research (Hamilton 2017). The discipline's permanent identity crisis, as manifested by, e.g., recurring debates, as well as all the other difficulties that theorizing on an abstract supranational level pose for studying religion in IR are an opportunity to popularize the post-secular approach, which increasingly appears to be the only one that is truly rational.

An interdisciplinary approach to studying international relations provides for a closer examination of the emerging "post-secular identity of IR studies" in this part of the article. Here, it is worth invoking the overall reassessment of learning, and to the philosophy of science and the evolving post-secular philosophical and sociological post-secular thought in particular and considering any influence they might have on IR study trends. Applying the percepts put forward by the young Polish philosopher, Miłosz Puczydłowski, through the prism of two mediated hermeneutic matrices (religious and secular) can prove very useful for molding this IR identity.

E. Bellin takes the view that, contrary to, e.g., comparative politics, the development of research into religion on IR has been necessitated by events powered by religion and is therefore empirical (Bellin 2008). Religion can no longer be ignored by virtue of its influence on the growth of international relations and because it is far more challenging than it has been to date (Snyder 2011, p. 1). It would be hard to disagree with the researchers, although this idea suggests another. It is our view that religion plays a considerably more important role in IR. It is the benchmark of the credibility of theoretical considerations of the events unfolding in the international area, and its conspicuousness in the "globalization" of the IR discipline means that it can "spread" to many other social sciences, thereby influencing their necessary transformation in this postmodernist age. IR therefore has an important scientific function to perform. The post-secular identity of IR is an opportunity and a lifeline for a discipline that has not been able to find its place in the scientific system. The proviso, however, is overcoming what Bellin noticed. Therefore, it is not on the basis of empiricism but on rational considerations on religion in IR that have been evolving for several decades and which are heading towards the carving out of a separate subdiscipline, ${ }^{2}$ while taking into account the arguments of those opposed to having religion included, that it is necessary to recognize and name, and consequently construct, a post-secular identity for the discipline. While the present considerations are merely a small contribution to this issue, they are hopefully a step in the right direction.

In the social sciences, we still seem unaware of the revolution that took place in our knowledge of the world due to quantum physics. We are at a place where science and philosophy stand shoulder to shoulder, just as they did in ancient times, before setting off on the long road to modernity. This is especially evident in the language used to describe nature in layperson's terms. In "God and the New Physics", Paul Davies writes about quantum entanglement as follows: "The electron keeps its options open until you actually peek. Both possible worlds exist in a hybrid, ghostly superposition" (Davies 1984). Moreover, this "awareness" (and hence the observer) reduces the quantum probability wave (Adamczyk 2012), although it is also possible that "every state really exists", and that Schrödinger's cat is therefore simultaneously alive and dead, but in two parallel universes.

From these few sentences, which are merely an approximation of real and certain scientific discoveries (after all, they are the basis of modern technology) and are difficult to reconcile with our (Newtonian) view of the world, it follows that a reassessment is underway wherever we use our reason. This is not only true of the natural sciences, but also of the humanities in the broadest sense. However, until we are able to learn more and discover additional laws that will better explain the complex natural and social reality to us, we must make do with philosophy. This philosophy makes the "shifting of the boundaries of rationality" (Życiński 2013) possible and is essential if we are to understand the world. In these circumstances, God, and religion, by virtue of their stubborn persistence in the lives and consciousness of many people, can once again become a useful phenomenon for the development of science-a phenomenon that brings with it the conviction that the world is 
governed by universal laws that can be comprehended by human reason. In the 17 th and 18th centuries, the religiousness of Pascal or Newton gave impetus to the development of modern science, and later, in a similar vein, it was the conviction of the brilliant agnostic Einstein saying "God does not play dice" which proved to be an extremely useful tool for guiding science into the next stage of its development, irrational as it may have seemed at first glance. For religion, on the other hand, entering once again into the orbit of science offers the hope of halting the integrist and fundamentalist tendencies that are dangerous to it. In social life, such tendencies often give rise to violence and thus distort the image of religion.

Contrary to popular opinion, it is metaphysics rather than new facts or tools that determine the revolution in science (Amsterdamski 1973, p. 32). When we observe the transition from medieval to modern physics, following S. Amsterdamski, we can state that Copernicus or Newton were confident in their claims not because they had new empirical evidence or improved research tools, but because they had certain metaphysical beliefs, and their "metaphysical and theological concepts were the guarantee of the logical coherence" of their physical or philosophical systems (ibid). It seems worthwhile to apply these observations to the study of international relations as well. We recommend that IR scholars cease focusing solely on the empirical evidence in support of the importance of religion in international relations. Having given the issue rational consideration, it would do well to undertake a revolution of sorts on this basis. Use of the term "revolution" means introducing a post-secular identity of the discipline. Such a metaphysical change can be implemented by the "post-secular turn" or "post-secular consciousness" — a complex philosophical concept composed of various currents of thought. The concept will make it possible to explain international reality in a new way, to understand it better and, consequently, shape it in a way that is useful for humans.

Recent revaluations in the philosophy of science have proved significant for IR especially during the "third/fourth debate" (Wight 2012, p. 39). The lesson that IR researchers have learnt from challenging the positivist paradigm is that there is no "definitive or agreed canon of scientific explanation", so the scientific method (science) is not equivalent to a positivist method (Ibidem:41). This way, a door has been opened for scientific yet post-positivistic research on religion, which positivism excluded from such research or, at best, reduced it to its bare material aspects. These are not the essence of religion (they merely denote cult, organisation, doctrine, and religious ethics, without reference to their perception and realisation in people's lives, i.e., without reference to the real influence that religion has on the decisions people make). In our opinion, the essence of religion is the transcendent sphere, which is excluded by positivism and is not subject to empirical research. However, the transcendent sphere is real and perceptible to those who believe because it is the relationship between this sphere and the believer (and both are expressed very differently across religions). It also goes far beyond the earthly condition of man. ${ }^{3}$

\section{Mediated Hermeneutic Matrices, or a Different Perspective on Post-Secularism}

According to most scholars, post-secularism in IR should be understood either as a recognition and an attempt to incorporate "religious arguments" into international theory and research (the return of religion from exile), or a critical approach to the "power of secularism", as already mentioned in this text (Mavelli and Petito 2012, p. 931; cf. E. S. Hurd 2008 and later publications). We wish to introduce a third way of understanding post-secularism in IR, which we believe can become the basis of the post-secular identity of the discipline we postulate. It is important to emphasize at this point that the metaphysical post-secular turn has occurred in Western culture, and it is from this that the essential core of IR research has grown. In this understanding, however, post-secular identity cannot mean the recognition of the pre-Enlightenment role of religion in social life and a return to it in science. ${ }^{4}$ The hermeneutical matrix of secularism, which at the dawn of European modernity appeared alongside the medieval religious matrix, has not ceased to exist; for many it remains the only matrix worthy of the label "science". However, 
it cannot be integrist, an argument it uses against religion. Post-secular identity is thus created by becoming aware of the mediation of both hermeneutic matrices: religion and secularity. Both are external observers of each other, and their mutual observation makes them permanently intertwined and dependent on each other (Puczydłowski 2017). It is hard not to recognise an analogy to the discoveries of quantum mechanics in this image.

As pointed out by M. Puczydłowski, today, where there is no religion there is no secularism, either-and where there is no secularism, there is no religion: "religion, after being embroiled in conflict with European atheism and secular ideology, is unable to return to its previous form" (Puczydłowski 2017, p. 31). Moreover, "the disappearance of religion does not mean the triumph of the secular paradigm, but its elimination" (Puczydłowski 2017, p. 32). Puczydłowski also defends the surprising claim that the vitality of the secularism-religion dispute is proof that "both formations still exist, are active and inevitably mediate their self-understanding in the self-understanding of the opposing side" (Ibidem: 32).

This post-secular philosophy is, in our opinion, a hope for IR studies and their permanent identity crisis (Grenier et al. 2015). It is clear that the identity of a discipline implies the collective identity of its creators-IR scholars. Their awareness of the link and mediation between religion and secularism may prove to be extremely important for a better understanding and explanation of international relations in the age of globalisation. In our opinion, the identity changes are also fostered by the generational changes that are taking place in the research community. In the West, researchers who had already built their worldview in the period of the "return of religion" and the revaluation of secularization theories are becoming more prominent. This is also facilitated by the fact that, in pursuit of the observed reality, IR studies are also becoming truly global. They are moving away from their Western roots and the associated limitations. More researchers from all over the world, for whom religion is often an important point of reference, are becoming involved in research in the field. Besides, in the aftermath of phenomena such as the financial crisis (2008), the immigration crisis (2015), and the Covid crisis (2021), researchers are increasingly beginning to speak of the decline of the West (Kuźniar 2017) and the decline of the concept of progress (Krasnodębski 1991). Some of them may even feel a degree of regret when they ask the question "Why has liberalism failed?" (Deneen 2018). This shift also signals an emergent recognition of religion, which is now perceived as a cultural rebellion placed in opposition to the domination of the secularised and liberal western world. It is not only in IR, but also in other social sciences that we see the need for a "decolonization of the secular/post-secular dyad" (Beaumont et al. 2018, p. 1). It turns out that thymos, or, as F. Fukuyama put it, "the part of the soul that craves recognition of dignity" (Fukuyama 2018, p. 9), determines identity changes not only in social life but also among the researchers who observe them.

\section{In Search of a Post-Secular Identity for IR Studies}

Studies of religion, having multiplied rapidly for decades (which, as Bellin observes could clearly be tied to events driven by religion), have eased off in recent years. As they were largely focused on militant Islam, they burned out with the defeat of Al-Qaeda and the Islamic State and the waning influence of the Islamic Republic of Iran. This, in turn, could be linked to the declining popularity of political Islam in general. Scholars guided by empiricism could therefore claim that the issue of religion had lost its urgency. ${ }^{5}$ However, the Taliban's resumption of power in Afghanistan in August 2021, and the rivalry between fundamentalists (including the bloody bomb attacks in Kabul) that this has unleashed, indisputably signal the return of the "issue of Islam", and consequently religion, to these studies. It is difficult to predict whether the Taliban will drop any of the demands of their religious program or enter the international community on "Westphalian" terms. It has to be borne in mind that very little is known about what is guiding their decisions, including their foreign policy decisions, because religion is still a factor that appears too infrequently and is insufficiently explored in IR studies. 
Hence, despite the "easing off", religion has once more come bursting onto the international stage, although mainstream IR studies obstinately reject it as irrelevant or at best impossible or "too difficult" for scholarly judgment (Sandal and James 2011). In our view, however, the problem primarily rests squarely with the convictions of scholars frequently described in the literature as having a "secularist bias" (Bar-Maoz 2016). Emphasis is laid on the genetic connection of this prejudice in favor of "Westphalian terms", which, as it is generally accepted, form the substratum of modern international relations (Thomas 2005). However, nothing that has a significant impact on the growth of a field of social life that is an object of study can remain outside scholarly judgment. As with other momentous events and processes in international relations (e.g., the collapse of bipolarity or globalization), religion undermines the foundations of the contemporary system of nations and should therefore find its place in mainstream studies. P. Berger's inspiring comment about US professors and Iranian mullahs is coming back to haunt us. These reflections follow the trail of this sociologist. We are trying to encourage these "professors", and everyone else, to be open to "religious arguments" that help create contemporary international relations. However, their secular convictions prevent these scholars from being noticed. Consequently, they do not contribute much to ir/IR, despite their considerable potential (as the post-secularists argue).

Along with the trend of reflecting on religion in IR, as an indirect reaction to international developments, especially militant Islam (discussed above), another more profound research trend seems to have developed since 2001. The late 2010s witnessed a sharp increase in publications on religion in IR. Many referred to and reflected on recently conducted studies. There were often disputes and greater openness to signals from other disciplines and the philosophy of science. We repose our greatest hope in this trend because we recognize its role in building a post-secular identity of the entire discipline. J. Haynes, among many others, in numerous publications, has not only systematized studies and made his own contributions (e.g., the concept of religion as a soft force, and studies on the dialog of civilizations) but has also reflected on the thoughts of other authors and systematized and commented on the discussions between them. He calls attention to several such polemics in a recent article (e.g., debates between Fitzgerald and Kubalkova, and Philpott and Shah with Hurd and others) (Haynes 2021). Systematizing articles by Xu (2012), Sheikh (2012), Schwarz and Lynch (2016) (cf. Solarz 2017) and many others also comprise an instructive summary of the deliberations of religion in IR. Attempts to reconcile religion with IR theory, an issue that J. Fox and N. Sandal, N. Sandal and P. James, J. Troy, Snyder and the nine authors of his book, and others, have grappled with, are also important. All these treatments demonstrate that studies on having religion included in mainstream IR studies are becoming increasingly mature and are consequently (although few would define it this way) forging a new post-secular identity of this discipline.

It is worth turning once more to the thoughts of Puczydłowski when searching for a new, post-secular IR identity. Having deeply and thoroughly analyzed the insights of various philosophers, sociologists, and theologians engaged in the "secularization dispute"-from Weber, Marx, Nietzsche to Barth, Bonhoeffer, Gogarten, Cox, Altizera and many others-Puczydłowski has been attempting to prove that this dispute is really a "bilateral mediation (obustronne zapośredniczenie) of two great interpretative narratives", each of which defines the hermeneutical term "matrix". All those he cites sought arguments in support or opposition of one of these matrices. However, as Puczydłowski notes, none were tempted to "reflect theoretically from above", and none gave any thought to the structure of the ongoing controversy. This situation changed at the turn of the 21st century through the intercession of figures such as Hans Blumenberg, Jurgen Habermas, John Milibank and Charles Taylor. While their interpretations of secularization vary considerably, they are united in rising above the secularized-religious debate and in effecting its meta description (Puczydłowski 2017, pp. 257-58). They are all creating a post-secular philosophy and thereby significantly contributing to the "post-secular turn" in the social sciences, and to a different "development of post-secular awareness". Being 
aware of the existence of this meta-description can also assist in reassessing the identity of IR in the direction of its post-secular component.

Puczydłowski identifies two groups that can be distinguished from among the thinkers he designates (and others) as being currently involved in the "secularization dispute": (i) those defending the Enlightenment heritage and attempting to demonstrate the superiority of secular ideas over religious thought; and (ii) those challenging the autonomy of contemporary thought, deeming it the "illegitimate child" of religion, and viewing secular language as a "mutant theological discourse" that best demonstrates the primacy of the religious matrix (Puczydłowski 2017, p. 259). Consider a scale on which the primacy of the Enlightenment (and the complete subordination of the religious matrix) is at one end and the reverse (the primacy of religion and the complete subordination of the secular matrix) at the other. Each of these philosophers, in his/her individual reflections, is obviously located at a different place on this scale. Puczydłowski considers Blumenberg and Milibank to be members of opposing factions, although, whereas he places them both fairly close to the ends of these segments, he has Habermas and Taylor much nearer the center. Habermas is placed on the side that designates the primacy of the Enlightenment whereas Taylor is on the side that designates the primacy of religion (Puczydłowski 2017).

Puczydłowski's observations on the mediation of the two matrices, which is carried out in the spirit of a more or less demonstrated superiority of either secularism (Blumenberg and Habermas) or religion (Milibank and Taylor) in the reflections of philosophers, has enormous significance for the impact of post-secular thought in the social sciences, including IR. Discerning these differences makes post-secular identity appear to be a complex phenomenon in which proponents of having the Enlightenment prevail over religion and advocates of the superiority of religion (treated as a metanarrative) can both be found. This also implies openness to "global IR", i.e., taking account of studies from various regions and cultures, including Hindu, Jewish, Islamic and African, where the incorporation of religion is a sine qua non for inclusion in a mainstream IR study. In this spirit, it would be worth analyzing the output of CE European scholars in addition to the many works that have recently been coming out in the West. It is our view that the first tendency (primacy of the Enlightenment) forms part of the thought of K. E. Brown and the authors she edited in a 2020 edition of International Affairs (Brown 2020). The second is represented by, e.g., M. Barbato (2020), L. Mavelli (2012), and J. Troy (2021).

The construction of a post-secular identity for IR studies could be considered a fait accompli if every scholar made an effort to specify his/her position on the segment marked by the two mediated hermeneutic matrices, thereby acknowledging the importance of post-secular philosophy to his/her approach to the international reality being studied. That is because, irrespective of how far apart scholars might be on this axis, they are permanently united by the conviction that religion matters and that it makes sense to refer to it as a cultural and political phenomenon. It is worth concluding with a quote from Scott Thomas, one of the pioneers of incorporating religion into studies on international relations: "What counts as religious, secular or political in any given context is not only socially constructed; it is a function of different configurations of power surrounding the construction of the categories of the religious, the secular and the political—and the boundaries between them" (Thomas 2014, p. 317). We believe that this quotation makes profound sense and that it is not only applicable to religion, secularism and politics but also to IR studies seeking their post-secular identity.

\section{Conclusions}

While Nietzsche's renowned reflection, quoted famously on the cover page of Time magazine, "God is dead", has become one of the best know symbols of our times, Heidegger's observation from the 1970s, "Only God can save us", has not gained even the smallest degree of popularity (Cerella 2014, p. 957). Removal of religion from the public space seems to have rooted itself very deeply both as an element of conventional wisdom and a scientific approach in the area of contemporary ir and IR. Changing the old secularist 
habit will certainly be a difficult task, but it seems no other option is possible in a world where religious actors and religious ideas constantly shape not only contemporary man and entire societies but also the highly complex international environment.

Research on religion in IR is approaching the stage of maturity. It is not just the observation of events powered by religious fuel, but also rational deliberation over the globalized world, with its advantages and disadvantages, inclined to reflect on religion. This also means reflecting on the secularism that is deeply inscribed in the genetic code of the discipline. There is no turning back from incorporating religion into discipline and from theorizing on it, but there is also no turning back from re-evaluating secularism that does not respond properly to the process of social development and possessing knowledge on it on the global scale. An open-ended question emerges of how to persuade the reluctant IR researchers to accept this epochal change in their discipline and what consequences this will bring in the area of IR.

Thanks to the evolving post-secular thought that is taking root more and more deeply in IR studies, and the changing philosophy of science, it seems that this may take the form of a new post-secular identity of the discipline. Because this requires from the scholars paying more attention to their own ontological assumptions (Schwarz and Lynch 2016) and making an attempt to transcend them, more inclusive, more holistic and more "ontologically just" (Wilson 2017) analyses of mutual relations between the secular and the religious shall emerge as a consequence. Such a redefinition would open the field not just to a broad, non-Western perspectives. It would also imply an uneasy reconsideration on the side of the Western scholars on their own reductionist perception of this complex issue. As a result, the problem of an authoritative, exclusivist discourse within the discipline could be solved. At the same time, allowing for more space in the discussion could mean not just better comprehension and interpretation but also more effective application of the analyzed phenomena directed at more dialogical and less confrontational links between the religious and the secular.

In the article, we propose a slightly different approach to post-secularism, as we point namely to the mutual mediation of both hermeneutic matrices-religious and secular. Any IR researcher is able to find a place between the two extreme attitudes, as long as he or she accepts this mediation and allows the arguments of both sides to be publicly debated. The new identity of researchers, and thus of the discipline constructed in this manner, is a guarantee of a more adequate assessment of the international reality. All of this requires further in-depth research because our deliberations are only the beginning of realizing the new identity. One should agree here with Mariano Barbato and Petr Kratochwil that global village "is worth a mass".

Author Contributions: Conceptualization, J.K and A.M.S.; methodology, J.K and A.M.S.; software, J.K. and A.M.S.; validation, J.K. and A.M.S.; formal analysis, J.K. and A.M.S.; investigation, J.K. and A.M.S.; resources, J.K. and A.M.S.; data curation, J.K. and A.M.S.; writing-original draft preparation, J.K. and A.M.S.; writing-review and editing, J.K. and A.M.S.; visualization, J.K. and A.M.S.; supervision, J.K. and A.M.S.; project administration, does not apply.; funding acquisition, does not apply. All authors have read and agreed to the published version of the manuscript.

Funding: No external funding was received.

Institutional Review Board Statement: Not applicable.

Informed Consent Statement: Not applicable.

Conflicts of Interest: The authors declare no conflict of interest.

\section{Notes}

There are several views on the origins of IR. (Cf. Grenier et al. 2015; Bierzanek 1972, p. 8; Haliżak 2015).

2 V. Kubalkova has proposed to define this as International Political Theology (MTP) (Kubalkova 2003). However, general agreement on this name, which indicates the theological nature of the discussion, would be difficult to obtain. Given the mediated hermeneutic matrices that shape the post-secular nature of this sub-discipline, and other currents of which it could be comprised 
(discussed further in the text), it is our view that it would be worthwhile to come up with a name that emphasized this broader perspective. International Post-Secular Studies might be a good idea. MTP would be included in these studies as one of their main currents.

3 Defining religion is not the purpose of this article due to the well-known problems arising from such attempts. However, we do address the issue as it would be difficult not to refer to it at all. At the same time, we are aware of all the associated limitations.

4 In the words of T. Halík: "Before the Age of Enlightenment, "religion" did not exist as a phenomenon alongside other sociocultural phenomena, but it "permeated everything", and was the air that everyone breathed. Throughout the Middle Ages, religion was a sort of materia matrix for all areas of social life." (Halík 2006, pp. 26-27, quote from: Puczydłowski 2017, p. 27).

5 In his review of studies of religion in ir/IR, J. Haynes primarily considers events connected with political Islam to be watershed moments (e.g., the 1979 Iranian Revolution, 9/11 in the USA, and the collapse of Al-Qaeda and the Islamic State in the first two decades of the 21st century). However, he also emphasizes the importance of e.g., the war in the former Yugoslavia and the fall of communism in Europe to the growth of these studies. He appears to consider the cooling off of the online conflict between the USA and political Islam as symptomatic of the declining significance of religion in ir. (cf. Haynes 2017, 2021).

\section{References}

Adamczyk, Adam. 2012. Kim Jest Kwantowy Obserwator? Available online: https://www.kwantowo.pl/2012/11/29/kim-jestobserwator (accessed on 22 August 2021).

Amsterdamski, Stefan. 1973. Między Doświadczeniem a Metafizyka. Warszawa: Książka i Wiedza.

Appleby, Scott R. 2021. Comprehending Religion in Global Affairs: Toward a Postsecular Paradigm of Religious Engagement to Advance Human Fraternity. In Human Fraternity and Inclusive Citizenship. Interreligious Engagement in the Mediterranean. Edited by Fabio Petito, Fadi Daou and Michael D. Driessen. Milan: LediPublishing, pp. 67-85.

Appleby, Scott R., Richard Cizik R., and Thomas Wright. 2010. Engaging Religious Communities Abroad: A New Imperative for U.S. Foreign Policy. Chicago: Chicago Council of Global Affairs.

Barbato, Mariano. 2012. Postsecular revolution: Religion after the end of history. Review of International Studies 38: 1079-97. [CrossRef]

Barbato, Mariano. 2020. Postsecular Plurality in the Middle East: Expanding the Postsecular Approach to a Power Politics of Becoming. Religions 11: 162. [CrossRef]

Barbato, Mariano, and Friedrich Kratochwil. 2008. Habermas's Notion of a Post-Secular Society. A Perspective from International Relations. San Dominico di Fiesole: European University Institute.

Bar-Maoz, Moria. 2016. The secularity of security: The secularist bias of modern security studies and its impact on international relations. Paper presented at the CEEISA-ISA 2016 Joint International Conference, Ljubljana, Slovenia, June 23-25.

Beaumont, Justin, Klaus Eder, and Eduardo Mendieta. 2018. Reflexive secularization? Concepts, processes and antagonism of postsecularity. European Journal of Social Theory 23: 291-309. [CrossRef]

Bellin, Eva. 2008. Faith in Politics: New Trends in the Study of Religion and Politics. World Politics 60: 315-47. [CrossRef]

Berger, Peter. 1999. The Desecularization of the World: A Global Overview. In The Desecularization of the World: Resurgent Religion and World Politics. Edited by Peter Berger. Washington DC: Ethics and Public Policy Center.

Bierzanek, Remigiusz. 1972. Współczesne Stosunki Międzynarodowe. Warszawa: Państwowy Instytut Wydawniczy.

Brown, Kartherine E. 2020. Introduction: Engaging religions and religious studies in international affairs. International Affairs 96: 275-78. [CrossRef]

Buzan, Barry, and Amitav Acharya. 2019. The Making of Global International Relations. Origins and Evolution of IR at Its Centenary. New York: Cambridge University Press.

Casanova, Jose. 1994. Public Religions in the Modern World. Chicago: University of Chicago Press.

Cerella, Antonio. 2014. Postsecular encounters in World Politics. Millenium: Journal of International Studies 42: 957-65. [CrossRef]

Davies, Paul. 1984. God and New Physics. New York: Simon \& Schuster.

Deneen, Patrick J. 2018. Why Liberalism Failed. New Haven and London: Yale University Press.

Eisenstadt, Samuel. 2005. Religious Origins of Modern Radicalism. Theoria: A Journal of Social and Political Theory 106: 51-80. [CrossRef]

Falk, Richard. 2014. Achieving Political Legitimacy in the Twenty-First Century. In Towards a Postsecular International Politics: New Forms of Community, Identity and Power. Edited by Luca Mavelli and Fabio Petito. New York: Palgrave Macmillan.

Fokas, Effie. 2009. Religion: Towards a Postsecular Europe? In Sage Handbook of European Studies. London: Sage.

Fukuyama, Francis. 2018. Identity: The Demand for Dignity and the Politics of Resentment. New York: Farrar.

Gierycz, Michał. 2021. Mała Pochwała Katolicyzmu. Kościót i Polityka w Późnej Nowoczesności. Warszawa: Teologia polityczna.

Gopin, Marc. 2000. Between Eden and Armageddon: The Future of World Religions, Violence and Peacemaking. New York: Oxford University Press.

Grenier, Félix, Helen Louise Turton, and Phillipe Beaulieu-Brossard. 2015. The struggle over the identity of IR: What is at stake in the disciplinary debate within and beyond academia? International Relations 29: 242-69. [CrossRef]

Habermas, Jurgen. 2008. Notes on Post-Secular Society. Available online: http:/ /www.signandsight.com/features/1714.html (accessed on 30 October 2010).

Halík, Thomas. 2006. Wzywany czy Niewzywany: Bóg się Tutaj Zjawi. Kraków: Wydawnictwo WAM.

Haliżak, Edward. 2015. Przedmiot, teoria i metodologia nauki o stosunkach międzynarodowych. Stosunki Międzynarodowe-International Relations 51: 11-33. 
Hamilton, Scott. 2017. A genealogy of metatheory in IR: How “ontology" emerged from inter-paradigm debate. International Theory 9: 136-70. [CrossRef]

Haynes, Jeffrey. 2014. Faith-Based Organizations at the European Union and United Nations: From Marginalization to Significance. In Towards a Postsecular International Politics: New Forms of Community, Identity and Power. Edited by Luca Mavelli and Fabio Petito. New York: Palgrave Macmillan.

Haynes, Jeffrey. 2017. Religion and Foreign Policy. Available online: https:/ / oxfordre.com/politics/view/10.1093/acrefore/97801902 28637.001.0001/acrefore-9780190228637-e-380 (accessed on 3 August 2021).

Haynes, Jeffrey. 2021. Religion and International Relations: What Do We Know and How Do We Know It? Religions 12: 328. [CrossRef]

Heller, Michał. 2021. Jerzy Baczyński z ks. Prof. Michałem Hellerem o kryzysie w Kościele i jak pogodzić religię z nauką. Polityka 14: 18-21.

Huntington, Samuel. 2005. Zderzenie Cywilizacji i Nowy Kształt Ładu Światowego. Warszawa: Muza.

Hurd, Elizabeth Shakman. 2008. The Politics of Secularism in International Relations. Princeton and Oxford: Princeton University Press. Inglehart, Ronald. 2021. Religion's Sudden Decline. What's Causing It, and What Comes Next? New York: Oxford University Press.

Kepel, Gilles. 2010. Zemsta Boga. Religijna Rekonkwista Świata. Warszawa: Wydawnictwo Krytyki Politycznej.

Krasnodębski, Zdzisław. 1991. Upadek Idei Postepu. Warszawa: Państwowy Instytut Wydawniczy.

Kratochwil, Friedrich. 2005. Religion and (Inter-)National: On the Heuristics of Identities, Structures and Agents. Alternatives 30: 114-30. [CrossRef]

Kubalkova, Vendulka. 2003. Towards an International Political Theology. In Religion in International Relations. The Return from Exile. Edited by Petito Fabio and Pavlos Hatzopulos. New York: Palgrave Macmillan, pp. 79-105.

Kulska, Joanna. 2020. Religious Engagement and the Migration Issue: Towards Reconciling Political and Moral Duty. Religions 11: 236. [CrossRef]

Kuźniar, Roman. 2017. Liberalny interwencjonizm Zachodu po zimnej wojnie-przesłanki i konsekwencje. In Wojny Zachodu. Edited by Madej Marek. Warszawa: Wydawnictwo Naukowe Scholar.

Madeley, John, and Zsolt Eneydi. 2003. Church and State in Contemporary Europe. The Chimera of Neutrality. London: Frank Cass Publishers.

Marsden, Lee. 2012. Bush, Obama and a Faith-based US Foreign Policy. International Affairs 88: 953-74. [CrossRef]

Mavelli, Luca. 2012. Europe's Encounter with Islam: The Secular and the Postsecular. Abingdon and New York: Routledge.

Mavelli, Luca, and Fabio Petito. 2012. The postsecular in International Relations: An overview. Review of International Studies 38: 931-42. [CrossRef]

Mavelli, Luca, and Fabio Petito. 2014. Towards a Postsecular International Politics. In Towards a Postsecular International Politics: New Forms of Community, Identity, and Power. Edited by Luca Mavelli and Fabio Petito. New York: Palgrave Macmillan.

Misztal, Bronisław. 2000. Teoria socjologiczna a praktyka społeczna. Kraków: Universitas.

Norris, Pippa, and Ronald Inglehart. 2004. Sacred and Secular. Religion and World Politics. New York: Cambridge University Press.

Petito, Fabio, and Scott M. Thomas. 2015. Encounter, Dialogue and Knowledge: Italy as a Special Case of Religious Engagement in Foreign Policy. The Review of Faith and International Affairs 13: 40-51. [CrossRef]

Petito, Fabio, Fadi Daou, and Michael D. Driessen. 2021. Fraternity, Citizenship and Interreligious Engagement. In Human Fraternity and Inclusive Citizenship. Interreligious Engagement in the Mediterranean. Edited by Fabio Petito, Fadi Daou and Michael D. Driessen. Milan: Ledi Publishing.

Petito, Fabio, Stephanie Berry, and Maria Mancinelli. 2018. Interreligious Engagement Strategies: A Policy Tool to Advance Freedom of Religion or Belief. Sussex: University of Sussex.

Pew Research Center. 2017. Religious Belief and National Belonging in Central and Eastern Europe. Available online: https: / / www.pewforum.org/2017/05/10/religious-belief-and-national-belonging-in-central-and-eastern-europe/ (accessed on 29 September 2021).

Philpott, Daniel. 2002. The Challenge of September 11 to Secularism in International Relations. World Politics 55: 66-95.

Philpott, Daniel. 2009. Has the Study of Global Politics Found Religion. Annual Review of Political Science 2: 182-202. [CrossRef]

Puczydłowski, Miłosz. 2017. Religia i sekularyzm. Wspótczesny spór o sekularyzację. Kraków: Universitas.

Ratzinger, Joseph, and Jürgen Habermas. 2006. The Dialectics of Secularization: On Reason and Religion. San Francisco: Ignatius Press.

Sandal, Nukhet A., and Patrick James. 2011. Religion and International Relations Theory. European Journal of International Relations 17: 3. [CrossRef]

Schwarz, Tanya B., and Cecelia Lynch. 2016. Religion in International Relations. Available online: https:/ / oxfordre.com/politics/ view/10.1093/acrefore/9780190228637.001.0001/acrefore-9780190228637-e-122 (accessed on 13 September 2021).

Shani, Giorgio. 2014. Religion, Identity and Human Security. New York: Routledge.

Sheikh, Mona Konwal. 2012. How daoes religion matter? Pathways to religion in Interantional Relations. Review of International Studies 38: 365-92. [CrossRef]

Singleton, Andrew. 2014. Religion, Culture and Society. A Global Approach. London: Sage Publications.

Snyder, Jack, ed. 2011. Religion and International Relations Theory. New York: Columbia University Press.

Solarz, Anna M. 2017. “Jakie znaczenie ma religia?”. Religia w badaniu stosunków międzynarodowych. Stosunki MiędzynarodoweInternational Relations 53: 9-35.

Stumvoll, Alexander A. 2013. Review article. Revista de Ciencia Politica 33: 715-20. 
Thomas, Scott M. 2014. Culture, Religion and Violence: Rene Girard's Mimetic Theory. Millennium-Journal of International Studies 43: 308-27. [CrossRef]

Thomas, Scott M. 2005. The Global Resurgence of Religion and the Transformation of International Relations: The Struggle for the Soul of the Twenty-First Century. New York: Palgrave Macmillan.

Tickner, Arlene B., and David L. Blaney. 2012. Introduction: Thinking difference. In Thinking International Relations Differently. Edited by Arlene B. Tickner and David L. Blaney. New York: Routledge.

Toft, Monica D., Daniel Philpott Timothy, and S. Shah. 2011. God's Century: Resurgent Religion and Global Politics. New York: W.W. Norton \& Company Inc.

Troy, Jodok. 2021. International politics as global politics from below: Pope Francis on global politics. Journal of International Relations and Development 24: 555-73. [CrossRef]

Wight, Collin. 2012. Philosophy of Social science and International Relations. In Handbook of International Relations, 2nd ed. Edited by Walter Carlsnaes, Thomas Risse and Beth A. Simmons. London: SAGE Publications Ltd.

Wilson, Erin K. 2010. Beyond Dualism: Expanded Understandings of religion and Global Justice. International Studies Quaterly 54: 733-54. [CrossRef]

Wilson, Erin K. 2012. After Secularism: Rethinking Religion in Global Politics. New York: Palgrave Macmillan.

Wilson, Erin K. 2017. "Power Differences" and "the Power of Difference": The Dominance of Secularism as Ontological Injustice. Globalization 14: 1076-93. [CrossRef]

World Values Survey. 2021. Available online: https://www.worldvaluessurvey.org/WVSContents.jsp?CMSID=Findings\&CMSID= Findings (accessed on 4 May 2021).

Xu, Yihua. 2012. Religion and International Relations in the Age of Globalization. Journal of Middle Eastern and Islamic Studies (in Asia) 6: 19-50. [CrossRef]

Życiński, Józef. 2013. Granice Racjonalności. Kraków: Pertus. 